\title{
Moderasi Islam Pada Tafsir Sunda Ayat Suci Lenyepaneun Karya Mohammad Emon Hasim
}

\author{
Irfan Setia Permana ${ }^{1}$, Ari Prayoga ${ }^{2}$, Della Shelvira ${ }^{3}$ \\ ${ }^{1}$ Politeknik TEDC Bandung \\ ${ }^{2}$ Edutech Madrasah Indonesia \\ ${ }^{3}$ Sekolah Alam Ibnu Hajar Bogor \\ 1Email: irfanspw@poltektedc.ac.id, 2ariprayoga@madrasah.id, \\ ${ }^{3}$ dellashelvira@saibnuhajar.sch.id
}

\begin{abstract}
Al-Quran and al-Hadith are the main sources of reference in Islam, Islam is a religion blessed by Allab SWT which was conveyed by Rasulullah Saw to Muslims, in al-Quran it is mentioned if Muslims are the best ummah, the chosen ummah and the just ummah. . In the reality of the life of Muslims, it is the opposite, for example the emergence of radical groups and liberal groups, the debate on the matter of Furn 'iyah. The purpose of this research is to examine 2 issues, namely: How the interpretation of Moh. Emon Hasim on the concept of Moderation in the scope of Islam according to Moh. Emoh Hasim and the interpretation of Moh. Emon Hasim on the verses of wasathiyah. This research uses the method of maudhu'i (thematic), library research (Library Research) is qualitative descriptive. Data search technique is by way of documentation (photos) of books related to this research. The results show that there are two sources of data that form the basis of this study; first, the primary data source by using Tafsir Ayat Suci Lenyepaneun by Moh. Emon Hasim son of al-Qur'an al-Karim. Second, secondary data sources can be from works such as, books, scientific works or journals that have relevance to this research. The conclusion is sourced from Moh. Emon Hasim in the interpretation of the holy verses Lenyepaneun wasathan ummah which is the ummah that can uphold justice, balance and tolerant behavior towards human beings, as described in Surat alBaqarah verse 143, Surat al-Maidah verse 89, Surat al-Adiyat verse 5, Surat al-Qalam verse 28 and Surat al-Baqarah verse 238. describes the principles of moderation in the scope of Islam and the behavior of moderate Muslims in accordance with the Qur'an, which is described as 3 terms, term adl in Surat al - Baqarah verse 282, surat al-Baqarah verse 124, and alHadid verse 25, the term tawazun in Surat al-Infithar verse 6- 7, Surat ar-Rabman verse 7 and al-Mulk. verse 3, the term tasamuh is in Surat al - Imran verse 64, Surat al-Imran verse 159 and Surat al-Kafirun verses $1-6$.
\end{abstract}

Keywords: Islam; lenyepaneun; Moderation; interpretation of holy verses. 


\begin{abstract}
Abstrak
Al- Quran serta al- Hadis ialah sumber referensi utama dalam beragama Islam, Islam agama yang dirahmati Allah Swt yang di sampaikan oleh Rasulullah Saw kepada umat Islam, dalam al- Quran di sebutkan jika umat Islam ialah umat terbaik, umat pilihan serta umat yang adil. Dalam realita kehidupan Umat Islam justru sebaliknya, misal timbulnya kelompok radikal serta kelompok liberal, Perdebatan mengenai perkara Furu' iyah. Tujuan penelitian ini yaitu mengkaji 2 perihal yaitu: Bagaimana penafsiran Moh. Emon Hasim tentang konsep Moderasi dalam lingkup Islam menurut pemikiran Moh. Emoh Hasim serta penafsiran Moh. Emon Hasim terhadap ayat- ayat wasathiyah. Penelitian ini menggunakan metode maudhu'i (tematik), penelitian kepustakaan (Library Research) bersifat deskriptif kualitatif. Teknik pencarian data yakni dengan cara dokumentasi (foto) buku-buku yang berkaitan dengan penelitian ini. Hasil penelitian menunjukan bahwa ada dua sumber data yang menjadi landasan dalam penelitian ini; pertama, sumber data primer dengan menggunakan Tafsir Ayat Suci Lenyepaneun karya Moh. Emon Hasim dan al- Qur'an al-Karim. Kedua, sumber data sekunder di dapat dari karya-karya seperti, buku, karya ilmiah atau jurnal yang memiliki revelansi tehadap penelitian ini. Kesimpulan bersumber pada Moh. Emon Hasim dalam tafsir Ayat suci Lenyepaneun ummatan wasathan yang ialah umat yang bisa menegakkan keadilan, penyeimbang serta perilaku toleransi terhadap manusia, sebagaimana yang dipaparkan dalam Surat al- Baqarah ayat 143, Surat al- Maidah ayat 89, Surat al- Adiyat ayat 5, Surat al- Qalam ayat 28 serta Surat al- Baqarah ayat 238. memaparkan mengenai prinsip- prinsip moderasi dalam lingkup Islam dan perilaku umat Islam yang moderat yang sesuai dengan al- Qur' an, yang di uraikan ke sebagai 3 term, term adl dalam Surat alBaqarah ayat 282, surat al- Baqarah ayat 124, serta al- Hadid ayat 25, term tawazun dalam Surat al- Infithar ayat 6- 7, Surat ar- Rahman ayat 7 serta al- Mulk ayat 3, term tasamuh ialah pada Surat al- Imran ayat 64, Surat al- Imran ayat 159 serta Surat al- Kafirun ayat 1- 6.
\end{abstract}

Kata Kunci: Islam; lenyepaneun; moderasi; tafsir ayat suci.

\title{
Pendahuluan
}

Referensi beragama dalam Islam yang sangat utama al- Quran serta al- Hadis, tetapi fenomena menampilkan jika wajah Islam sangat banyak, Islam terkadang mempunyai khas sendiri- sendiri dalam praktek serta amaliah keagamaan. Tampaknya perbandingan itu telah 
menjadi kewajaran, sunatullah, serta terlebih lagi suatu rahmat. ${ }^{1}$ Quraish Shihab berkata kalau: Keanekaragaman dalam kehidupan ialah keniscahyaan yang dikehendaki Allah. Tercantum dalam hal ini perbandingan serta keanekaragaman pendapat dalam bidang ilmiah, apalagi keanekaragaman tanggapan manusia menyangkut kebenaran kitab- kitab suci, penafsiran kandunganna dan untuk pengalamannya. ${ }^{2}$ Yang jadi permasalahan yakni dapatkah dari yang berbeda tersebut untuk bersama menghormati, tidak sama- sama menyalahkan, tidak meyatakan paling benar sendiri, serta besedia bedialog sehingga tercermin kalau perbandingan itu betul- betul rahmat. Bila ini yang dijadikan pijakan dalam beramal serta beragama, sehingga inilah sesungguhnya arti konsep Islam moderat. Maksudnya siapa juga orangnya dalam beragama bisa bersikap sebagaimana kriteria tersebut, sehingga bisa disebut dengan Islam yang moderat. ${ }^{3}$

Islam Moderat bisa merujuk kepada praktek Islam yang dicoba oleh Nabi Muhamammad SAW serta para sahabatnya, khususnya Alhulafa al-Rashidin, sedangkan dalam kontek Indonesia bisa merujuk kepada para penyebar Islam yang populer dengan sebutan Walisongo, artinya Islam di harapkan bisa jadi bagian serta pemecahan dari perkara bangsa, agama serta Negeri, ataupun perkara yang global disaat ini. ${ }^{4}$ Krisis dunia internasional pada saat ini telah sedemikian kompleks sehingga Islam dituntut agar dapat turut serta di dalamnya, hal tersebut menjadi tanggungjawab dari Islam sebagai ajaran agama yang ramah serta jadi rahmat di tengah-tengah konflik di berbagai belahan dunia. ${ }^{5}$

${ }^{1}$ Nor Elysa Rahmawati, "Penafsiran Muhammad Thalibi Tentang Ummatan Wasathan Dalam Al-Qur'an" (UIN Sunan Kalijaga Yogyakarta, 2014), 3.

${ }^{2}$ Muhammad Quraish Shihab, Membumikan Al-Qur'an (Jakarta: Lentera Hati, 2010), 23.

${ }^{3}$ M. Amien Rais, Cakrawala Islam: Antara Cita Dan Fakta (Bandung: Mizan, 1991), 20.

4 Sabri Mide, "Ummatan Wasathan Dalam Al-Qur'an" (UIN Alaluddin Makassar, 2014), 2.

${ }^{5}$ A. Mustofa Bisri, Islam Mazhab Tengah, 1st ed. (Jakarta: Grafindo Khazanah Ilmu, 2007), 17. 
Jadi jelas kalau Islam merupakan rahmat untuk umat manusia yang sudah dibawa oleh Rasulullah SAW selaku risalah, sebagaimana di jelaskan dalam Surat Al- Anbiya ayat 107.6 Maka dari itu umat muslim wajib betul- betul memahami jika Islam merupakan agama Allah, yang maksudnya tiap umat Islam memikul tanggung jawab untuk memperjuangkannya. Hendaknya Islam jadi program hidup untuk menjalankan menjadi akidah manusia, sebagai hukum dalam pergaulan hidup serta jadi cara hidup untuk manusia. Dalam al- Qur' an sudah disebutkan bahwa Allah menjanjikan umat Islam sebagai umat terbaik, umat pilihan serta umat yang adil. Islam yang semestinya ialah agama yang adil, ramah, berperadaban besar serta terletak di barisan sangat depan. Tetapi yang bisa di temui hari ini wajah Islam yang sebaliknya. ${ }^{7}$

Kasus yang berlangsung pada umat di Indonesia pada umumnya tentang pemahaman terhadap ajaran Islam, ialah terdapatnya perbedaan dalam beragama serta bermadzhab, Islam itu satu, namun metode memahaminya yang bermacam- macam. Perihal ini menimbulkan istilah- istilah ataupun lebel dalam Islam itu sendiri. Misalnya kelompok Radikal serta kelompok Liberal. ${ }^{8}$ Kecenderungan pemahaman radikalisme dalam Islam sangat ekstrim serta ketat dalam menguasai hukum- hukum agama( Islam) serta berupaya memaksakan metode tersebut dengan memakai kekerasan di tengah warga Muslim. Di Indonesia ada sebagian kelompok pemikiran serta gerakan Islam di Indonesia yang di cap selaku kelompok yang radikal, di antara kelompok Islam merupakan mereka yang bergabung dalam jamaah Negeri Islam Indonesia( NII), Hisbut Tahrir Indonesia( HTI), dan Front pemuda Islam surakarta( FPIS) serta Majelis Mujahidin Indonesia( MMI). ${ }^{9}$

\footnotetext{
${ }^{6}$ Kementerian Agama Republik Indonesia, Al-Qur'an Dan Terjemahnya (Jakarta: Lajnah Pentashihan al-Qur'an, 2005), 508.

7 Rahmawati, "Penafsiran Muhammad Thalibi Tentang Ummatan Wasathan Dalam Al-Qur'an.", 5.

8 Andi Aderus Banua, Kontruksi Islam Moderat: Menguap Prinsip Rasionalitas, Humanitas, Dan Universitas Islam, 1st ed. (Makassar: ICATT Press, 2012), 5.

${ }^{9}$ Afadlal, Islam Dan Radikalisme Di Indonesia, 1st ed. (Jakarta: LIPI Press, 2005), 104-105.
} 
Salafi Wahabi ialah kelompok yang cenderung berkeinginan untuk melaksanakan verifikasi dengan metode melakukan ajaran Islam sesuai dengan kehidupan Nabi serta Khulafaurrasyidin. NII serta HTI ialah organisasi yang fundamentalis, sebab keduanya tidak mengakui sendi-sendi negeri sekuler yang bersumber pada hukum buatan manusia. Ada pula MMI dengan tokoh sentralnya Abu Bakar Baasyir dianggap memiliki ikatan dengan jamaah Islamiyah yang diduga selaku organisasi teroris oleh PBB. FPIS merupakan organisasi yang memiliki aktivitas intens digolongan anak-anak muda surakarta selaku media buat merespon problematika sosial yang terdapat di wilayah tersebut. ${ }^{10}$ Sebagian kelompok di atas menyuarakan gagasan dalam permasalahan pelaksanaan syariat Islam ataupun mendirikan agama Islam. Upaya mereka dalam mendirikan Negeri Islam yang secara totalitas menginginkan pemberlakuan hukum Islam. Sebaliknya liberalisme dapat dilihat pada perilaku longgar secara ekstrim dalam kehidupan beragama serta tunduk pada prilaku serta pemikiran yang asing apabila dilihat dari perkembangan tradisi Islam. ${ }^{11}$

Sebagian penyebabnya di atas menekan untuk mangulas lebih mendalam kandungan arti moderasi dalam al- Quran. Riset ini di harapkan jadi sesuatu upaya untuk mencari nilai- nilai Moderasi dalam lingkup Islam, yang menjadikan salah satu jawaban dari kegelisahan- kegelisahan yang jadi titik fokus riset ini. Islam Merupakan agama yang Moderat dalam penafsiran tidak mengarahkan perilaku ekstrim dalam bermacam aspeknya, penafsiran ini didasarkan atas statment dalam salah satu ayat al- Qur' an yang membagikan tuntunan hidup kepada umat Islam. Yang diartikan dengan moderat ialah sesuatu pemikiran pemikiran yang tidak membenarkan serta menolak terbentuknya kekerasan atasnama negeri, semacam permasalahan terorismeyang diucap sebagian golongan selaku aksi jihad, permasalahan terorisme dalam sebagian tahun ini jadi kejadian yang tengah gencar serta marak- maraknya. ${ }^{12}$

\footnotetext{
${ }^{10}$ Afadlal, Islam Dan Radikalisme Di Indonesia, 107.

${ }^{11}$ Afadlal, Islam Dan Radikalisme Di Indonesia, 125.

12 Rahmawati, "Penafsiran Muhammad Thalibi Tentang Ummatan Wasathan Dalam Al-Qur'an.", 6.
} 
Disisi lain Islam Mengarahkan untuk bersikap moderat sebagaimana yang sudah dipaparkan di atas, namun disisi lain Islam Moderat dengan pertumbuhan era saat ini ini sudah tidak terlihat lagi wajah Islam yang Moderat, Sebagian permasalahan intoleran/ islam yang tidak moderat ialah Ormas Front Jihad Islam( FJI) mendatangi Pondok Pesantren Waria Al- Fatah Kotagede, Jagalan, Banguntapan, Bantul. Mereka memohon supaya pondok pesantren ditutup. Beberapa masyarakat menolak Camat Pajangan Yulius Suharto di Kabupaten Bantul sebab yang bersangkutan nonmuslim. Sementara itu, Bupati Bantul, Suharsono, telah melantiknya. Pembatalan Kegiatan Kebaktian Nasional Reformasi 500 Tahun Gereja Tuhan oleh Stephen Thong Evangelistic International( STEMI) di Yogyakarta, sebab terdapat penolakan dari ormas Islam dengan tuduhan kristenisasi. Beberapa ormas Islam menolak aktivitas bakti sosial Paroki Gereja Santo Paulus, Pringgolayan, Bantul, dalam kegiatan memeringati 32 tahun berdirinya gereja. Sebab penolakan merupakan upaya kristenisasi serta mereka memohon panitia gereja memindahkan aktivitas di gereja. Forum Ukhuwah Islamiyah( FUI) menghadiri kantor humas serta admisi Universitas Kristen Duta Wacana( UKDW) Yogyakarta. Mereka memprotes poster iklan penerimaan mahasiswa baru UKDW yang menunjukkan gambar perempuan berjilbab. Hingga dari itu Para mufasir yang tidak sedikit mangulas menimpa Moderasi Islam dalam kitab tafsirnya. Salah satu mufasiryang mangulas ayatayat Wasathiyah merupakan Moh. Emon Hasim, ia dikategorikan selaku mufassir kontemporer sebab kitab tafsirnya ditulis mulai dari tahun 1989, kitab Tafsir Ayat Suci Lenyepaneun yang terdiri dari 30 jilid ia menulis dengan memakai bahasa Sunda beraksara Roman yang otentik. ${ }^{13}$

Penafsiran yang dimunculkan oleh Moh. Emon Hasim bisa menyentuh seluruh kalangan, sebab dalam menafsirkan ayat- ayat alQur'an, ia memakai bahasa serta analogi yang gampang dimengerti. Moh Emon Hasim muncul serta melaksanakan pembahasaan terhadap ayat- ayat Wasathiyah dalam tafsirnya dengan pengertian yang

13 Jajang A Rohmana, Sejarah Tafsir Al-Qur'an Di Tatar Sunda (Bandung: Mujahid Press, 2017), 161. 
relevan dengan kontek saat ini ini. Tidak hanya pada aspek metodologisnya, tafsir Lenyepaneun cenderung lebih menonjol pada nuansa bahasa serta sastra Sunda di dalamnya, paling utama pada pemakaian ungkapan tradisional Sunda, cerminan alam pasundan untuk memperkaya uraian tafsirnya serta bawa nuansa alam pikiran pembaca. ${ }^{14}$

Berbagai ungkapan tradisional sunda( babasan[ungkapan], paribasa [peribahasa] serta kecap- kecapan) perihal ini jadi aspek bernilai dalam kekhasan tafsirnya. ${ }^{15}$ Ungkapan tradisional inilah ialah bagian dari keahliannya dalam memakai ungkapan tradisional. Riset ini butuh dikaji lebih lanjut sebab tokoh Moh. Emon Hasim kerapkali memakai diksi sunda yang berirama serta serasi dalam suara, ini yang mencerminkan karakter Hasim selaku orang sunda. Serta inilah salah satu kelebihan Tafsir Ayat Lenyepaneun dalam bahasa bahasa sunda yang dipergunakannya. ${ }^{16}$

\section{Metode Penelitian}

Sebagaimana pengumpulan data penelitian ini bersumber dari kepustakaan (Library Reseach), maka pola kerjanya bersifat Deskriptif

${ }^{14}$ Babasan yaitu ucapan tertentu yang digunakan dalam arti kiasan, biasanya merupakan kalimat tidak sempurna, paribasa berupa perumpaman dalam menjalani kehidupan, biasanya merupakan kalimat sempurna, kecap yaitu ucapan yang sudah tetap untuk menyampaikan perasaan dengan bahasa yang dapat menggambarkan maksud penuturnya secara tepat dan serasi. Rohmana, Sejarah Tafsir Al-Qur'an Di Tatar Sunda, 162.

15 Babasan yaitu ucapan tertentu yang digunakan dalam arti kiasan, biasanya merupakan kalimat tidak sempurna, paribasa berupa perumpaman dalam menjalani kehidupan, biasanya merupakan kalimat sempurna, kecap yaitu ucapan yang sudah tetap untuk menyampaikan perasaan dengan bahasa yang dapat menggambarkan maksud penuturnya secara tepat dan serasi. Rohmana, Sejarah Tafsir Al-Qur'an Di Tatar Sunda, 163.

16 Mohammad Emon Hasim, Pengalaman Nyusun Naskah Ayat Suci Leunyepaneun, dalam perhimpunan Keluarga Besar Pelajar Islam Indonesia (Perhimpunan KB-PII), Ngamumule Budaya Sunda Nanjeurkeun Komara Agama, Lokakarya Dakwah Islam Napak kana Budaya Sunda, Lihat juga. Mohammad Emon Hasim, Ayat Suci Lenyepaneun (Bandung: Pustaka Setia, 1989), V. 
Kualitatif. ${ }^{17}$ Serta dianalisis dengan menggunakan Analisis Sosiologis (Sociologic Analysis) analisis ini digunakan untuk menganalisis sisi kemasyarakatannya yang terkandung dalam konteks sekarang ini. Penelitian ini menggunakan metode maudhu'i (tematik), metode ini sangat populer dikalangan mufasir, juga metode maudhu'i dikenal dengan metode paling mudah dalam menafsirkan al-Qur'an. Dengan menggunakan metode ini diharapkan dapat menjawab persoalan yang muncul saat ini atau menjadikan pengetahuan dalam bidang ulumul Qur'an.

Pencarian sumber data dilakukan dengan metode dokumentasi( foto) buku- buku yang berkaitan. Tipe sumber informasi ini dibagi menjadi dua, ialah sumber informasi primer serta sumber informasi sekunder. ${ }^{18}$ Sumber data primer dari riset ini merupakan alQur'an al-karim serta Penafsiran Moh. Emon Hasim menimpa ayatayat Wasathiyah dalam Tafsir Ayat Suci Lenyepaneun yang ialah tafsir becorak adabi al- Ijtima'i, sumber data sekunder ialah dari buku- buku, karya ilmiah ataupun jurnal yang berhubungandengan Moderasi Islam pada Tafsir Ayat Suci Lenyepaneun. Pengumpulan data dicoba dengan metode analisis dokumentasi, mengingat tipe riset ini terkategori dalam riset pustaka (library research) ${ }^{19}$ Data- data tertulis semacam tafsir, buku, jurnal serta riset terdahulu dikumpulkan serta diolah, setelah itu di analisis. Analisis data yang digunakan merupakan Deskriptif Analisis, informasi dicoba dengan metode memaparkan, menguraikan serta menganalisis sisi sosiologis penafsiran Moh Emon Hasim terhadap ayat- ayat wasathiyah pada Tafsir Ayat Suci Lenyepaneun. ${ }^{20}$

17 Lexy J. Moleong, Metodologi Penelitian Kualitatif (Bandung: PT. Remaja Rosdakarya, 1989), 4.

${ }^{18}$ Noor Juliansyah, Metodologi Penelitian (Jakarta: Kencana, 2011), 137.

${ }_{19}$ Rahmawati, "Penafsiran Muhammad Thalibi Tentang Ummatan Wasathan Dalam Al-Qur'an.", 18.

${ }^{20}$ Ahmad Izzan, Metodologi Ilmu Tafsir. (Bandung: Tafakur, 2011), 45. 


\section{Hasil Penelitian dan Pembahasan}

\section{A. Biografi Mohammad Emon Hasim}

Moh. E. Hasim (Mohammad Emon Hasim) dilahirkan di Ciamis pada bertepatan pada 15 Agustus 1916 di Kampung Bangbayang Kidul, Kawali Kabupaten Ciamis. Diketahui selaku guru serta penulis tafsir. Hasim memahami bahasa Belanda, Inggris, Arab, serta Jepang. Hasim kecil mengenyam pembelajaran dasar di Sekolah Desa sepanjang 3 tahun dilanjutkan ke Schakelschool(sekolah rakyat) Muhammadiyah serta Hollandsch- Inlandsche School (HIS) kemudian dilanjutkan ke sekolah menengah awal Meer Uitgebreid Lager Onderwijs (MULO), serta juga pernah melanjutkan ke Algemeene Middelbare School (AMS). ${ }^{21}$

Hasim pernah menjadi guru sekolah rakyat, sejak masa pendudukan Jepang, kemudian dipindahkan ke kantor kabupaten menjadi boei Karicho yaitu sebagai pengerah tenaga kerja untuk menjadi Seinendan dan Keibodan merangkap sebagai juru bahasa. Kemudian diberikan tugas untuk memimpin Persatuan Perjuangan Nasional yaitu gabungan sabilillah, Hisbulloh, tentara pelajar dan BBRI. Beberapa kali ditangkap belanda, menjadi tahanan rumah dan melarikan diri ke Bandung. Di Bandung, Hasim mengajar SMP PARKI sambil merangkap sebagai sekretaris non-kooperator dan memimpin kantor Urusan Demobilisan Pelajar. Setelah pensiun, Hasim memulai untuk belajar agama bahasa Arab dengan sendiri, kemudian menulis buku-buku agama dalam bahasa sunda termasuk tafsir Ayat Suci Lenyepaneun (1990-1993). ${ }^{22}$

Dengan karya inilah, pada tanggal 10 April 1994 ia mendapatkan penghargaan dari sastra Rancage dalam kategori kara berbahasa sunda pada 31 Januari 2001. Hasim meninggal pada hari Minggu, 3 Mei 2009 di Rumah Sakit Hasan sadikin, pada usia 93 Tahun dengan meninggalkan sepuluh orang anak. ${ }^{23}$

${ }^{21}$ Jajang A Rohmana, “Ideologisasi Tafsir Lokal Berbahasa Sunda: Kepentingan Islam-Modernis Dalam Tafsir Nurul-Bajan Dan Ayat Suci Lenyepaneun," Journal Of Qur'an And Hadith Studies 2, no. 1 (June 2013): 125-154.

${ }^{22}$ Rohmana, Sejarah Tafsir Al-Qur'an Di Tatar Sunda, 131-132.

${ }^{23}$ Ajib Rosidi, Ensiklopedia Sunda (Bandung: Pustaka Setia, 2007), 266. 


\section{B. Sejarah Perkembangan Tafsir Sunda}

Di Tatar Sunda, Tafsir di tulis dan diajarkan dalam beragam bahasa, tafsir berbahasa Arab banyak beredar di pesantren, ini merupakan elemen inti kurikulum, sementara tafsir sunda dan indonesia banyak beredar di masyarakat, adapula di pesantren tradisional yang masih menggunakan tafsir sunda beraksara Arab pegon, seperti Tafsir Jalalayn, tetapi dalam bahasa pengantarnya masih menggunakan bahasa lokal (Sunda atau jawa). ${ }^{24}$ Tujuan Tafsir diorientasikan yaitu untuk terwujudnya Fungsi utama al-Qur'an sebagai pedoman hidup manusia menuju kebahagiaan dunia dan akhirat. ${ }^{25}$

Oleh karena itu tafsir berasal dari bahasa Arab yaitu al-kasfu, wal bayan, wal mao'idzoh yang berarti menyingkap seuatu yang tertutup atau samar, menjelaskan makna yang dipahami oleh akal dari alQur'an dengan menjelaskan makna yang sulit atau belum jelas dan memerlukan penjelasan. ${ }^{26}$ Kajian al-Qur'an dalam bidang tafsir berbahasa sunda dimulai sejak H. Hasan Mustopa menulis Qur'anul Adhimiyaitu pada awal abad ke-20 dengan tulisan berbahasa sunda dan menggunakan aksara pegon. Pada saat yang bersamaan, diketahui Sanusi juga menulis karya tafsir berbahasa sunda dan melayu. ${ }^{27}$

Diantaranya yaitu; pangadjaran dengan bahasa sunda atau Majla al- Thalibin fi Tafsir Kalam Rabb al-'Alamin (tempat panyalindungan para santri dina nafsirkeun al-Qur'an) yang disusun sampai 9 Juz (QS. Al-A'raf) dalam 28 jilid tipis dengan menggunakan bahasa sunda aksara pegon yaitupada tahun 1931, sementara Raudhat al-Irfan fi $M a^{\prime}$ rifat al-Qur'an ditulis dengan menggunakan aksara pegon dengan sistim penulisan antar baris secara miring dan menggantung atau dikenal dengan logat gantung yaitu pada tahun 1931, tafsirnya secara singkat diletakan pada bagian pinggir, tafsirnya terdiri dari dua jilid

${ }^{24}$ Rohmana, Sejarah Tafsir Al-Qur'an Di Tatar Sunda, 86.

${ }^{25}$ Muhammad Abduh, Tafsir Al-Fatihah Wa Juz Amma (Kairo: Al-Hay'ah alAmmah li Qusur as Saqafah, 2000), 8.

${ }^{26}$ Mana Khali al-Qattan, Mahabit fi Ulum al-Qur'an, 323.

${ }^{27}$ Rohmana, Sejarah Tafsir Al-Qur'an Di Tatar Sunda, 87. 
(juz 1 s/d 15 juz, 16 s/d 30).28 Berbeda dengan Tafsir Tamsjijatoel Moeslimin fi Tafsierikalami Rabbil-'Alamien yang memicu pada polemik boleh tidaknya urang sunda menyusun tafsir al-Qur'an dengan menggunakan bahasa Melayu dengan aksara Roman, tafsir tersebut diketahui dan disambut baik oleh para ulama pesantren serta masyarakat luas..$^{29}$

Selain Mustapa dan Sanusi, sekitar akhir tahun 1920-an para aktifis gerakan persatuan Islam (PERSIS) diketahui menejemahkan pula Tafsir al-Foerqan, karya A Hasan guru persis) ke dalam bahasa sunda sebanyak tiga jilid. Penerjemahnya adalah dua orang guru agama Djoeragan Moh. Anwar Sanuci dan Djoeragan Moh. Djoenaedi dari Garut. Terjemah tafsir ini dilakukan kemungkinan banyaknya permintaan jama'ah persis yang belum tebiasa menggunakan bahasa melayu, saat itu persis memang sedang mengalami masa kemasan (kejayaan) di bawah bimbingan Tuan Hassan. Moehammad Anwar Sanusi juga tenyata menyusn tafsir yaitu Ghajatoel Bajan (Katjida Pertelana) tafsir Qur'an basa soenda jilid 1-5 pada tahun 1347/1928.30

Nama terakhir mufasir sunda yang mempublikasikan tafsir sunda pada era pra-kemerdekaan, pahlawan Nasional dan pendiri organisasi Persatuan Umat Islam (PUI) yaitu menulis tafsier soerat al$M a^{\prime}$ oen yang merupakan saduran bebas (pengambilan) dari tafsir Juz Amma karya Muhammad Abduh. Abdul Halim berusaha mendalami ajaran filantropi al-Qur'an, dalam surat tersebut dan menjadikannya sebagai basis praksis sosial dalam aktifitas kesehariannya diberbagai organisasi sosial, dan kitab tafsirTabarok pada tahun 1930-an. ${ }^{31}$ Pada era pasca kemerdekaan, karya tafsir semakin banyak, baik yang ditulis secara individu, kelompok bahkan merupakan proyek pemerintah, tetapi pada umumnya di tulis oleh kalangan Islam pebaharu. Romli

${ }^{28}$ Ahmad Sanusi, Raudhatul Al-Irfan Fi Ma'rifat Al-Qur'an (Sukabumi: Yayasan Asrama Pesantren Gunung Puyuh, 1950).

29 Dadang Darmawan, “Ortodoksi Tafsir: Respon Ulama Terhadap Tafsir Tamsjijatoel Moeslimin Karya K.H. Ahmad Sanusi" (Fakultas Ushuluddin UIN Syarif Hidayatullah Jakarta, 2009), 164.

${ }^{30}$ Moehammad Anwar Sanuci, Gajatoel Bajan (Katjida Pertelana), Tafsir Qoer'an Basa Soenda (Garut: Madjlis Ahli Soennah, 1982), 20.

${ }^{31}$ Abdul Chalim, Tafsir Soerat Al-Ma'oen (Madjalengka: Drukkerij, 1993), 45. 
dan H.S.N. Midjaja memulainya dengan menulis Nurul Bajan: Tafsir Qur'an Basa Sunda pada tahun 1960, karya ini ditulis dengan tulisan ejaan lama yang belum disempurnakan dan hanya sampai juz tiga (QS. Ali Imran [3]:91). Dalam tafsir ini banyak sumber yang digunakan sebagai rujukan yaitu pada Baidawi, Madarik al-Tanzil, Lubab al-Ta'wil, At-Tabari, al-Maraghi, Termasuk berbahasa inggris dan belanda. ${ }^{32}$

Pada tahun 1978, Pemprov dan Kanwil Depag jawa Barat menerbitkan terjemahan dan tafsir al-Qur'an bahasa sunda yang di pimpin oleh K.H. Anwar Musadad, karya resmi ini kemudian di sempurnakan kembali pada 1981 /1982 dengan mengeluarkan tafsir alQur'an basa Sunda sebanyak 6 jilid. Dilihat dari pola sistematikanya, karya ini mengikuti terjemah dan tafsir al-Qur'an yang diterbitkan dalam bahasa oleh Kementerian Agama RI pada waktu sebelumnya. Bahkan bisa dikatakan merupakan pengambilan dari tafsir Depag berbahasa Indonesia tesebut. Secara gagasan, isi tafsirnya sama saja yang membedakan hanya bahasanya saja. ${ }^{33}$

Penanggung jawab dari pihak Pemprov yaitu Gubernur jawa barat, Aang Kunaaepi kemudian dilanjutkan oleh Yogie S.M. kepala Kanwil Depag jabar. Nama Romli cukup populer karna dikenal dengan beberapa kali mempublikasikan karya terjemah dan tafsir sunda. Setelah Romli meninggal sekitar tahun 1981, kemudian digantikan oleh M. Hambali Ahmad. Riset ini disusun oleh Pemprov pada tahu 2011 yang sedang mempersiapkan kembali penyusunan tafsir sunda resmi yang direncankan selesai pada tahun 2012. ${ }^{34}$ Pada tahun 1984 dunia tafsir berbahasa sunda kemudian diramaikan oleh Moh. Emon Hasim (1916-2009) dengan menyusun karyanya yaitu Ayat Suci Lenyepaneun dalam 30 jilid, tafsir ini merupakan tafsir al-Qur'an pertama dalam bahasa sunda beraksara Roman. Lenyepaneun juga memberikan penjelasan yang disesuaikan dengan kehidupan seharihari masyarakat di tatar sunda dengan bahasa sunda lancaran yang

${ }^{32}$ Muhammad Romli and H. N. S. Midjaja Nurul Bajan, Tafsir Qur'an Basa Sunda Juz 1, 2nd ed. (Bandung: N. V. Perboe, 1966), 692.

${ }^{33}$ Rohmana, Sejarah Tafsir Al-Qur'an Di Tatar Sunda, 80.

${ }^{34}$ Kantor Wilayah Kementerian Agama Provinsi Jawa Barat, Tafsir Al-Qur'an Basa Sunda (Bandung: Pustaka Setia, 2005), vii. 
mudah di baca yang dihiasi dengan berbagai ungkapan tradisional Sunda. ${ }^{35}$

Kemudian muncul kencenderungan kembali karya tafsir yang beredar di tatar sunda yang meupakan terjemah dari beberapa karya tafsir berbahsa Indonesia atau Arab. Pada era tahun 40-an muncul tafsir Al-FoerqonBasa Sunda (1937) yang berasl dari bahasa melayu, kini muncul hal serupa, yaitu karya H. Oemar Bakry karya tafsirnya yaitu Tafsir Rahmat Basa Sunda (1986-2002). ${ }^{36}$ Karya ini merupakan edisi terjemahan yang tidak dilakukan oleh penulisnya ke dalam bahasa Indonesia, diterjemahkan dalam bahasa sunda yaitu oleh $\mathrm{H}$. M. Soelaeman salah satu Dosen ITB, beliau memiliki ketertarikan terhadap Tafsir Rahmat untuk disosialisasikan pada masyarakat sunda. Tetapi tafsir ini tidak menunjukan karaker bahasa sunda yang sebenarnya. ${ }^{37}$ Tafsir sunda juga ditulis Uu Suhendar, Tafsir Ar-Razi, Juz Amma jeung al-Fatihah pada tahun 2011.

\section{Sistematika Tafsir Ayat Suci Lenyepaneun}

Tafsir Ayat Suci Lenyepaneun adalah tafsir pertama yang berbahasa sunda dan beraksara roman yang orisinal, di tulis dengan kalimat-kalimat yang memikat dan mudah dimengerti, tafsir tersebut di tulis lengkap 30 juz, dalam satu jilid rata- rata 300-400 halaman. Dalam menyusun tafsir Ayat Suci Lenyepaneun Hasim memberikan ilustrasi peristiwa atau kejadian di Masyarakat yang relevan dengan ayat sehingga terasa masih aktual dan populer pada masanya. Metode Tafsir Ayat Suci Lenyepaneun menggunakan pendekatan tafsir bial$r a^{\prime} y$ dengan metode tahlili, dan corak hida'i atau adab al ijtima'i.38

Sistematika tafsir ini diawali dengan mencantumkan ayat yang akan dibahas disertai transliterasi Latin, kemudian dijelaskan arti kata demi kata dan uraian penafsiran dengan penjelasan atau keterangan maksud dari ayat tersebut sesuai dengan hasil temuannya. Sesekali

${ }^{35}$ Hasim, Ayat Suci Lenyepaneun, vi. 2002), 40.

${ }^{36}$ H. Oemar Bakry, Tafsir Rahmat Basa Sunda, 2nd ed. (Bandung: CV. Angkasa,

${ }^{37}$ Rohmana, Sejarah Tafsir Al-Qur'an Di Tatar Sunda, 92.

38 Rohmana, "Ideologisasi Tafsir Lokal Berbahasa Sunda: Kepentingan IslamModernis Dalam Tafsir Nurul-Bajan Dan Ayat Suci Lenyepaneun.", 37. 
menggunakan referensi asbab an-Nuzul dan hadis Nabi, dalam menyusun tafsir, Hasim menggunakan terjemah tafsir bahasa Indonesia dan bahasa asing, ditambah dengan kamus bahasa Sunda dan buku pengajran bahasa Arab dalam bahasa Inggris. ${ }^{39}$ Bahasa sunda lancaran yang digunakan sangat komunikatif dan berusaha menjelaskan sesuatu agar sesuai dengan alam pikiran orang sunda. Gaya penafsirannya mengingatkan pada model tafsir al-Azhar karya Hamka. Dalam penyusunan tafsir Ayat Suci Lenyepaneun dilatarbelakangi beberapa alasan di antaranya: keinginan untuk memelihara bahasa sunda ${ }^{40}$, juga dorongan untuk mempelajari agama langsung dari sumbernya dan kewajiban untuk menyampaikan serta pengalaman ketidakpuasaannya terhadap tafsir yang ada, baik metode ataupun bahasanya. ${ }^{41}$

Selain aspek motodologisnya, tafsir Ayat Suci Lenyepaneun cenderung terlihat nuansa bahasa dan sastra Sunda didalamnya, terutama pengunaan ungkapan tradisional Sunda gambaran alan dan cerita keseharian orang sunda. ${ }^{42}$ Hasim kerapkali menggunakan diksi bahasa sunda yang berirama dan serasi dalam suara, misalnya "Kitu munguhing kaadilan nu Maha adil, pantrang nanggeuy ti bongkokna, beda jeung kaadilan manusa di alam dunya; nu nylong endog dibarogod jeung diberok, bangsat gerot nu ngagorogot pada ringan ngeunah- ngeunah medah-meduh, lain bae aman teu digunasika malah pada ngadama-dama. ${ }^{43}$ Diksi yang berirama semacam ini mencerminkan kepribadian Hasim sebagai orang sunda yang sangat menyenangi keindahan bahasa Sunda.

Selain itu Hasim juga menceritakan cerita populer yang berasal dari pengalaman hidupnya atau boleh jadi terinspirasi berita di media massa. Tafsir sunda yang hadir jauh sebelum Indonesia terbentuk

39 Mohammad Emon Hasim, Pangalaman Nyusun Naskah Tafsir Ayat Suci Lenyepaneun (Bandung: Pustaka Setia, 1984), v.

${ }^{40}$ Mohammad Emon Hasim, Rupa-Rupa Upacara Sunda Jaman Ayena (Bandung: Pustaka Setia, 1996), v.

${ }^{41}$ Her Suganda and Mohammad Emon Hasim, Bekarya Sampai Tua (Bandung: Pustaka Setia, 2002), 12.

${ }^{42}$ Rohmana, Sejarah Tafsir Al-Qur'an Di Tatar Sunda, 163.

${ }^{43}$ Hasim, Ayat Suci Lenyepaneun, Jilid 1, 3. 
merupakan cerminan pengalaman keagamaan orang sunda dalam berdialog dengan kitab sucinya. Tafsir Ayat Suci lenyepaneun yang lahir dari seorang otodidak yang bukan dari lulusan pesantren. ${ }^{44}$ Dalam Tafsir Ayat Suci Lenyepaneun menggunakan motode tahlili yaitu dengan mengguraikan makna yang terkadung dalam ayat-ayat al-Qur'an dengan mengikuti susunan atau urutan surat dan ayat-ayat al-Qur'an yang diikuti oleh analisis tentang kandungan ayat. ${ }^{45}$ Contoh dalam tafsir Ayat Suci Lenyepaneun ang menunjukkan metode tahlili yaitu; Surat al-Baqarah 2:143: Hartina: Jeung kitu tah kami geus ngajadikeun maraneh ummat anu siger tengah sangkan maaneh jadi saksi ka balarea, jeung sangkan Rasul jadi saksi ka maneh. Jeung kami teu kapati-pati nyieun kiblat tempat maraneh madep anging sangkan kami nyaho saha anu nurut ka Rasul jeung saha anu nukang nonggong. Saeunyana pindah kiblat teh karasana beurat kacida kajaba pikeun jalma-jalma anu geus dipaparin pituduh ti Allah, jeung Allah moal rek ngaremehkeun iman maraneh. Satemenna Allah teh mikawelas mikaasih ka manusa. ${ }^{46}$

\begin{tabular}{|c|c|c|c|}
\hline Ummat & $\begin{array}{c}\text { Sami ngajadikeun } \\
\text { maraneh }\end{array}$ & 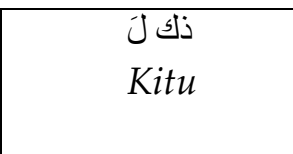 & $\begin{array}{l}\text { g } \\
\text { Jeung }\end{array}$ \\
\hline $\begin{array}{l}\varepsilon\lrcorner \\
K a\end{array}$ & 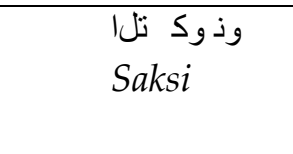 & $\begin{array}{c}\text { Sangkan maraneh } \\
\text { jadi }\end{array}$ & $\begin{array}{c}\text { اط سو } \\
\text { Sigeur tengah }\end{array}$ \\
\hline
\end{tabular}

Sumber: Moh. Emon Hasim, Tafsir Ayat Suci Lenyepaneun, Jilid 2, 2-3.

o:= ummat siger tengah hartina teu koret tapi teu ngamonyahmonyah rejeki, anceg bobot pangayon timbang taraju tara nanggeuy ti bongkokna tapi adil palamarta. ${ }^{47}$

Tafsir Ayat Suci Lenyepaneun merupakan tafsir yang becorak adabi al- Ijtima'i dengan mengunakan gambaran alam pasundan untuk memperkaya penjelasan tafsirnya dan alam pkiran pembacanya.

\footnotetext{
${ }^{44}$ Rohmana, Sejarah Tafsir Al-Qur'an Di Tatar Sunda, 170.

${ }^{45}$ Ahmad Izzan, Metodologi Ilmu Tafsir. (Bandung: Tafakur, 2011), 103.

${ }^{46}$ Hasim, Ayat Suci Lenyepaneun, 2-3.

${ }^{47}$ Hasim, Ayat Suci Lenyepaneun, 2-4.
} 
Contohnya yaitu dalam QS. Al-Baqarah 2: 221: Mojang-mojang ngalempereng koneng atawa jangjing kulitna semu hejo carulang, panon cureuleuk beungeutna ngadaun seureuh, pendek na mah ti luhur sasemet buuk ti handap sausap dampal matak moho nu nenjo, geulis tanding endah taya papadana matak ibur salelembur matak ear sajajagat. Tapi hanjakal sanajan geulis andalemi ampuh timpuh pikayunyuneun pikaheroyeun geuning dipiamis buah gintung, atina midua pikir ngijing sila bengkok sembah ka nu maha kawasa, musyrikat nu dila'nat ku mantena. Kageulisan pamikat jajaka nepi ka matak gandrung liwung kapirangung teh henteu lana umur geus tunggang gunun paling-paling ngan kari urutna, nya kolot nya peot, karajap-kerejep siga nu kapireupeunan. Kageulisan nu dijieun kaangkuhan jeung angkeuhan teh luntur $k u$ umur laas ku jaman, tapi iman nu ngancik dina ati anu suci, teu uggut kalinduan teu gedag kaanginan, manen nepika kalanggengan. Kusabab eta dina milih pibatureun sakasur omat ulah balbol kabongroy $k u$ bahenol, sanajan hideung tapi buah manggu leuwih alus batan lobi-lobi nu beureum euceuy. ${ }^{48}$

\section{Penafsiran Moh. Emon Hasim dalam Tafsir Ayat Suci Lenyepaneun}

\section{Term Wasat}

Term wasat ini berarti sesuatu yang memiliki dua ujung yang ukurannya sama, secara umum wasat berarti berada di tengah-tengah antara dua hal. ${ }^{49}$

a. Q.S. Al- Baqarah Ayat 143

Menurut penafsiran Quraish Shihab dalam tafsir Al-Misbah berpendapat bahwa yang dimaksud dengan ummatan wasathan (pertengahan) moderat dan teladan sehinga dengan posisi Ka'bah yang berada di pertengahan pula, dan posisi pertengahan yang menjadikan manusia tidakmemihak ke kiri dan ke kanan. Allah menjadikan umat Islam pada posisi pertengahan agar kamu, wahai umat Islam, menjadi saksi atas perbuatan manusia yakni umat yang lain, tetapi initidak dapat kalian lakukan kecuali jika kalian

\footnotetext{
${ }^{48}$ Hasim, Ayat Suci Lenyepaneun, 263.

49 Kementerian Agama Republik Indonesia, Moderasi Islam (Jakarta: Lajnah Pentashihan Mushaf al-Qur'an, 2014), 8.
} 
menjadikan Rasul Saw. syahid yakni saksi yakni yang menyaksian kebenaran sikap dan perbuatan kamu dan beliau pun kalian saksikan, yakni kalian jadikan teladan dalam segala tingkah laku..$^{50}$

Dari penafsiran ke dua Mufasir mengenai Umatan wasathan dalam Qs. Al- Baqarah ayat 143 terdapat perbedaan dalam mengemukakan pendapatnya, menurut Moh. Emon Hasim yang dimaksud umatan wasathan itu yakni umat yang tidak kikir tidak pula boros, tetapi pertengahan. Seimbang dan adil dalam melakukan kebaikan. Sedangkan menurut Quraish Shihab yang di kemukakan dalam tafsir al- Misbah yang di maksud dengan ummatan wasathan yaitu umat yang pertengahan tidak memihak ke kiri dan ke kanan (seimbang), sebagaimana tingkah laku Rasulullah. Secara analisis substansi dari kedua tafsiran tersebut adalah keseimbangan dan keadilan dalam menyikapi perbedaan.

b. Q.S Al-Adiyat Ayat 5

Nurutkeun HR. Al-Bazar, Ibnu al-Hatim jeng al-Hatim ti Ibn Abbas, Q.S al-adiyat ayat 1 nepi ka ayat 5 dilungsurkeun ku Gusti nu Maha Suci tumali jeung hiji kajadian sarombongan kavaleri nu diutus ku Rasulullah saw. geus sabulan lilana can mulang deui malah teu aya beja-bejana acan. Ku turunna ayat nu 5 ieu anjeunna uninga yen eta pasukan teh keur toh pati jiwa raga ngayonan musuh. Ayat-ayat ieu ngandung rineka sastra pikeun ngebrehkeun wadyabala nu leber ku wawanen dina ngalaksanakeun jihad fii sabilillah. Kuda lumpat ngabelesat napasna mani hoshosan tarik lir ibarat gandawesi ditekerkeun cahya pating burinyay lir ibarat gandawesi ditekerkeun kana seuneu. Sapanjang jalan nu kaliwatan ngadak-ngadak poek ku kekebul. Tah ieu teh pikeun ngagambarkeun para pahlawan nu teuneung ludeung taya karisi karingrang dinangabela agama. ${ }^{51}$

Menurut Hadis Riwayat Al-Bazar, Ibnu al-Hatim dan al-Hatim dari Ibn Abbas ayat 1 sampai ayat 5 di turunkannya oleh Allah yang Maha Suci berhubungan dengan satu kejadian satu kelompk kavaleri yang diutus oleh Rasulullah saw. Sudah satu bulan lamanya dan tidak ada kabarnya, dengan turunnya ayat ke 5 ini beliau mengetahui

${ }^{50}$ Muhammad Quraish Shihab, Tafsir Al-Misbah (Jakarta: Lentera Hati, 2002), 415.

${ }^{51}$ Hasim, Ayat Suci Lenyepaneun, 271. 
bahwa pasukan tersebut sedang melawan musuh. Pada ayat ini mengandung beragam sastra untuk mengungkapkan arti dalam jihad $f i$ Sabilillah, kuda perang larinya kencang, nafasnya bergerak kencang. Sepanjang jalan yang dilewati terasa gelap oleh debu. Ini merupakan gambaran terhadap pahlawan yang berani dalam membela agama Allah.

c. Q.S Al-Maidah Ayat 89

Pada surat al-maidah ayat 89 ini menjelaskan bahwa kita harus menjadi orang yang berbudi luhur oleh karena itu kita harus mengerjakan perbuatan yang telah di perintahkan oleh Allah swt, Allah yang telah memberi petunjuk untuk hambanya. Menurut Quraish Shihab ${ }^{52}$ menafsirkan dalam tafsir al-misbah menyebutkan kata wasath/pertengahan dalam arti makanan yang bisa dimakan, bukan hidangan istimewa. Ada juga yang memahaminya dalam arti yang terbaik. Memang kata tersebut bisa juga diartikan demikian, tetapi pendapat pertama lebih kuat, apalagi salah satu ciri agama Islam adalah moderasi, bahkan kebajikan adalah pertengahan antara dua ekstrem. ${ }^{53}$

Berdasarkan penafsiran Moh. Emon Hasim dalam surat alMaidah ayat 89 pertengahan dalam mengambil denda yaitu 2 baju atau 2 sarung yang satu masih bagus yang satu sudah lusuh atau sesuai dengan kemampuan. Term wasat juga digunakan untuk menunjukkan sesuatu yang berada di antara dua hal yang buruk, sebagaimana ayat di atas skap dermawan, yakni sikap yang berada di antara sikap boros dan kikir, dan juga susu yang murni, yakni yang berada pada darah dan kotoran. Maka dari sinilah, kata wasat dimaknai sebagai sikap moderat19(pertengahan), tidak ke kiri dan tidak ke kanan. Kata wasat juga bisa di pahami sebagai sifat yang lurus, adil, dan bersih. Atau secara umum, seseorang dikatakan wasat jika ia adalahorang pilihan dan danggap paling mulia. ${ }^{54}$

${ }^{52}$ Muhammad Quraish Shihab, Ensiklopedia Al-Qur'an Kajian Kosakata (Jakarta: Lentera Hati, 2017).

${ }_{53}$ Shihab, Tafsir Al-Misbah, Jilid 5, 233.

${ }^{54}$ Shihab, Tafsir Al-Misbah, Jilid 5, 233. 


\section{Term Al-Adl (keadilan)}

Keadilan yang dibicarakan dan tuntut oleh al-Qur'an amat beragam, tidak hanya proses pada penetapan hukum atau terhadap pihak yang berselisih, melainkan al-Qur'an juga menuntut keadilan terhadap diri sendiri, baik ketika berucap, menulis atau besikap batin. Pembahasan ini meliputi Q.S al-Baqarah: 282, Q.S al-Baqarah: 124, Q.S al-Hadid: 25.55

\section{a. Q.S. Al-Baqarah Ayat 282}

Dina urusan muamalah aya sababaraha rupa masalah di antarana urusan perekonomian. Jeung dina urusan perekonomian teh aya urusan jualbeuli nu dina agama mah disebut muawadhasulmaliah. Lamun urang meuli barang saeutik, boh saeutik jumlahna boh saeutik macemna teu dicatet ge teu naon-naon, nya kitu deui keur nu dagang balantik leuleutikan mah teu make catetan ge sarua bae teu naon- naon. Tah ieu teh dina jual-beuli secara kontan. Lamun nganjuk mah kudu make catetan malah alusna mah kudu make disebutkeun rek sabaraha kali jeung iraha dibayarna sangka repeh-rapih teu aya pacengkadan.Upama jual-beuli geus ngarekahan komo lamun geus mangrupa syirkah al-abdan atawa PT, koperasi jeung sabangsana pasti kudu make administrasi.

Dina ayat ieu aya kecap 凷 tukang nyatet kagiatan usaha, jadi kudu aya ahli pembukuan, oge aya kecap syuhadaa- untukan nyaksian beres heunteuna, jadi kudu aya badan pemeriksa nu tetep atawa panitia nu diwangun kupara ahli saperti akontan. Upama ku urang dilenyepan ayat ieu teh ngajurung laku ka ummat Islam supaya disagigireun jadi ulama ukrawiyah, oge kudu aya ulama dunyawiyah, kudu bisa nyusun sababaraha disiplin elmu diantarana, elmu tata buku, elmu akontasi, elmu managemen jeung sabangsana. Ari kanyataanna ayeuna saukur jadi tukang ngabuntu boroampar ngali nurutan ge bari ti paparagut, memang dina ayat ieu teu aya kekecapan, offerte, kwitansi, order, jornal, buku besar jeung sabagnsana, da memangna dina waktu turunna ieu ayat mah dina waktu perkembangan bisnis teh can nepi ka dinya, tapi jelas ayat ieu teh mangrupa sumber transaksi dina bisnis anu sehat, beresih dina kakaliruan jeung manipulasi. Upama urang daek ngayakeun muhasabah jeung muroqabah, daek ngoreksi

${ }^{55}$ Kementerian Agama Republik Indonesia, Moderasi Islam, 20. 
diri bari naliti kakurangan diri, sumber kaboyotan urangteh diantarana teu ngarti kan eusi al-Qur'an ar rajen bisa macana ngan sakur dihariringkeun balap paalus-alus sora sangka jadi juara jeng meunang piala. ${ }^{56}$

b. Q.S. Al-Baqarah Ayat 124

Nurutkeun HR. Ibnu Ishak jeung Ibnu Abi Hatim ti Ibnu 'Abbas, oge HR. Abd. Bin Humaid, Ibnu Jarir jeung Ibnu Abi Hatim ti al-Hasan, kalimat-kalimat nu dipake nyoba Nabi Ibrahim teh: 1. Parentah hijrah misahkeun diri kalembur batur, 2. Diduruk ka Raja Namrud, 3. Parentah ngurbankeun putrana, 4. Nolak nyembah bentan, bulan jeung panon poe, 4. Nolak nyembah bentang, bulan jeung pano poe, 5. Mayunan dua tamu anu teu daraekeun disuguhan, 6. Ngantunkeun isteri jeung orokna, Siti Hajar jeung Ismail di Bakah/Mekah, tempat hara-haraeun, garing, gundul taya jukut-jukut acan, katurug-turug loba sasatoan galak, turta duanana nunggelis teu sanak teu baraya, taya batur geusan pakumaha. ${ }^{57}$

Kabeh cocoba dilaksanakeun kalawan ihlas pasrah sumerah ka nu Maha Kawasa. Sanggeus lulus tina sagala rupa cocoba, anjeuna di angkat jadi imam pikeun sakabeh ummat manusa sangkan Iman ka Gusti Allah, pangeran nu Maha Esa, jeung ngaberesihan akidah tina rupa-rupa panyakit syirik, tug nepika ahir jaman. Ku sabab eta agama Islam ageman urang ayena disebut millata Ibrahim. Gusti Allah ngabulkeun pamundut Nabi Ibrahim, putrana Ismal jeng Ishak jadi Nabi jeung Nabi jeung Rasul. Sababaraha putra-putrana nu saroleh rundayan ti Nabi Ishak diangkat jadi Nabi jen Rasul jeung rundayan ti Nabi Ismail nya eta Nabi Muhammad. Ari jalmajalma nu teu adil, nu telenges taya rasrasan, nu sarakah jeng darolim mamh kabeh ge diapkir, sakumaha unggeling dawuhan Mantenna dina pamungkas ayat. 124 ieu: laa yanaalu 'ahdizhzhaalimiin- jangji kami henteu ngurung jalma-jalma nu darolim. 58

c. Q.S. Al-Hadid Ayat 25

Beusi secara hissiyah nya eta logam nu aya di jero taneuh, sanggeus diolah jadi gelempengan pajang, pasagi, buleud jeung lambaran. Kuat jeung gede pisan manfaatna, ti mimiti barang nu lalembut seperti jarum pentul nepi ka barang nu kacida galedena saperti mariem dijieun tina beusi atawa waja.

\footnotetext{
${ }^{56}$ Hasim, Ayat Suci Lenyepaneun, Juz 3, 66.

${ }^{57}$ Hasim, Ayat Suci Lenyepaneun, Juz 1, 281.

${ }^{58}$ Hasim, Ayat Suci Lenyepaneun, Juz 1, 282.
} 
Lamun teu aya beusi atawa waja moal aya pabrik, kapal laut, kapal laut, kapal udara, kareta api, mobil pakakas perang jeung rea-rea deui nu loba teuing upama ditataan kabeh.

Gusti Allah maparin Kitab, naraca atawa timbangan jeung beusi. Upama dihartikeun secara ma'nawiyah, bisa disaruakeun jeung trias politica, Kitab sumber hukum ibarat Badan Legislaif, naraca atawa timbangan ibarat Badan Yudikatif, jeung beusi nu ngandung kakuatan mangrupa rupa-rupa pakarang ibarat Badan Eksekutif. Ku ayana Kitab, naracaltimbangan jeung beusi teh manusa diparentah ngaheuyeuk dayeuh ngolah nagara kalayan jujur jeung adil malar ummat manusa rahayu salamet di dunya jeung di aherat. Ku nu tilu rupa ieu Gusti Allah bakal ngontrol manusa saha nu ta'at ka mantenna jeung ka para Rasul na, sanajan mantenna teh teu adu hareupan da Maha Goib tea, hamo bisa dibuktikeun hakekat zat na secara 'ainal yaqin.

Jadi keadilan dalam penafsiran Moh.Emon Hasim yaitu bukan hanya adil terhadap orang lain tetapi juga harus adil terhadap diri sendiri. Keadilan harus ditegakkan dalam situasi apapun, sebagaimana yang telah di jelaskan di atas.

\section{Term Tawazun (Keseimbangan)}

a. Q.S. Al-Infithar Ayat 6-7

Dina HR. Ibnu Abi Hatim ti Ikrimah disebutkeu yen Ubay bin Khalaf teu percayaeun kana ayena yaumul ba'atst, nya harita turun ayat 6: yeuh geuning kitu, katipu ku naon maneh teh nepi ka wani nukang nonggong ka pangeran maneh, nu Maha Mulya?

(birabikal kariim) bisa dihartikeun: ka pangeran maneh, nu Maha Welas Asih. Sebab nyat jeung karasa kurnia Mantenna nu lain itung-itungan deui. Naha pantes lamun urang ngijing sila bengkok sembah ka nu sakitu welas asihna? Naha uang teu ngarasa kahutangan budi ? kunaon pangna nepi ka kitu? Kapireupeunan dunya, pangkat, harta jeung kakawasaan? Kasenangan dunyawiyah teh paparin saha? Naha aya nu bisauen nyieun dunya salianti Gusti Allah?

Nu ngayuga dunya katut eusina teh taya lian iwal ti nu Maha Kawasa. Nu nyiptakeun nini-moyang, kuring jeung maneh taya deui iwal ti mantenna. Boga dedeg pangadeg nu pantes jeung sampurna, lengkap pancadrian, potongan saluyu jeung rupa, cik ku saha ari lain ku mantenna 
mah, pek baca ayat 8 jeung 9 tuluy lenyepan. Lamun sagala unak-anik nu aya dina badan urang kudu disambung sarungsum ku urang, rek meuli kamana, sabaraha pihargeun nana, jeung saha nu bakal bisa masangkeunnana? Labuh nepi ka misalah tuur ge geuning mulan malen ingkud-ingkudan, tatmba kamana mendigeus beak ratusan rebu can cageur-cegeur, komo lamun kudu ngaganti cacariuan $k u$ nu anyar mah rek kumaha bisa alusna. Sakitu mantenna Mika Welas mika Asih ka urang taya wates wangenna teh tapi naha make wani nganggap bohong kana dawuhan manenna ngeunaan yaumul ba'ast malah aya antekna. Tukadzibuuna bidiin, maneh nganggap bohong kana ayana wawales nu akal di tibankeun engke dina yaumiddin, kapan eta teh dawuhan mantenna, da Rasulullah mah saukur suku sambung lengah biwir sambung carek.

Rek percaya rek teu peraya, urang teh taya kendatna di kukuntit ku pangawas ngarangkep jadi juru catet, mahluk nu di mlakeun ku Gusti Allah. Saha tea? Malaikat Raqib jeung Atid, nu nyatetkeun sagala rupa ucap jeung lampah urang. Aranjeunna teterangeun saniskara nu dilakukeun $k u$ urang sanajan ku urang disumput-sumput oge. Pek tengetan ungeling 7 nepi ka ayat 12.

\section{b. Q.S. Ar-Rahman Ayat 7}

Gusti Allah geus ngalungsurkeun sababaraha ayat ngeunaan hukum kamasarakatan dina widang ahkamuddauliyah (hubungan antar nagara, peperangan, kaamanan, perekonomian, jste), ahkamul-jinaiyah (hukum pidana seperti urusan maling, maehan, jste), malah nepi ka urusan hukum rumah-tangga seperti kawin, talak, ruju, bagi waris, jste. Ku ayana hukum ieu teh supaya dina hirup kumbuh bener-bener aya kaadilan, henteu hirup ngaberung nurutkeun hawa napsu, henteu hawek, henteu mangpangmeungpeung, henteu mabok kakawasaan, jste.

c. Q.S. Al-Mulk Ayat 3

Langit tujuh lapis, bisa bener-bener tujuh, jeung bisa ngandung harti majazi nya eta pirang-pirang. Diantara nu tujuh atawa nu pirang-pirang teh nya eta langit alam syahadah, langit nu bisa dibuktikeun ku panon urang. Kolong langit alam syahadah teh sok disebut alam cakrawala. Hakekat alam cakrawala jeung langit nu sejenna teh hamo bisa bener-bener kahontal $k u$ panalar akal, sebab boloampar ngudag masalah goib nu mustahil bisa dipesek 
ku elmu pangaweruh manusa, dalah kaayaan alam syahadah ge lain guarguareun ku kamampuhan nu kadengker ku kaheureutan.

Kusabab elmu manusa teh beuki lila beuki mekar, tafsir ilmiah ngeunaan alam cakrawala teh robah terus, contona kolong langit alam syahadah cenah dieusi $k u 500$ milyar bentang jarah, ayeuna mah beda deui, cenah dieusi ku 100 juta bentang jarah, jadi lamun unggal-unggal galaksi sarua eusina, di kolong langit alam syahadah teh aya 100 milyar X 100 juta bentang jarah. Bisa jadi isuk atawa pageto mah robah deui.

Asal teu maen mutlak-mutlakan taya halangan nana nafsirkeun alam cakrawala secara ilmiah, pikeun nguatan iman yen kakawasaan pangeran $n u$ murbeng Alam teh luar biasa. Sebutkeun bae: "ieu teh nu geus bisa kahontal ku panalar akal nepi ka denget kiwari". Nitenan alam cakrawala secara ilmiah the sapagodos jeung timbalan Mantenna dina ayat ieu: pek ilikan deui, naha hidep nenjo nu pasolengkrah/nu teu saimbang.

Nurutkeun panenjo ilmiah, bentang tanpa wilangan di jalan cakrawala teh di bagi jadi pirangn-pirang tata surya atawa solar system. Unggal-unggal tata surya diwangun $k u$ hiji panon-poe, sababaraha planit jeung sababaraha satelit. Panon poe muter di tempat nu disebut rotating; marcapada (planit padumukan urang) muter bari ngurilingan panon-poe tina orbitna. Bulan (satelit marcapada) muter, ngurilingan marcapada bari milu ngurilingan panon-poe. Sakabeh planit jeung satelit sarua muter jeung nguriling, teu aya nu rundag randeg. Jeung teu aya nu kaluar tina orbitna masing-masing. Tah ieu teh sunatullah nu geus jalan jutaan taun. Teu aya nu silih teunggar nepi ka pasolengkrah, kabeh tunduk ka nu Maha Agung kalayan beres-reos jeung repeh-rapih.

Dalam penafsiran Moh. Emon Hasim mengenai keseimbangan (taawazun) yaitu manusia harus memperlakukan sesuatu itu dengan seimbang tidak berat ke kiri dan ke kanan, supaya tidak terjadi perpecahan (agar tetap damai/ada dalam tempatnya masing).

\section{Term Tasamuh (Toleransi)}

a. Q.S. Al-Imran ayat 64

Hayu urang nyekel kana hiji kalimat nu sarua; ngandung maksud ngajak kana hiji katetapan nu sarua, saluyu jeung tauhid dina agama samawi nu diwahyukeun Gusti ti mimiti Nabi Adam as nya eta: إنلادبنادا = yen 
henteu aya nu disembah $k u$ urang sarerea kajaba Allah. Lamun di antara panganut agama samawi aya nu boga anggapan yen disagedengeun Gusti Allah aya deui pangeran sejen nu murba wisesa, jelas maranehna teh geus nyeleweng tina tauhid nu asli. Kajadian panelewengan sarupa kieu teh geus biasa timbul dina waktu fatrah Nabi. Contona antara kaum Nabi Musa as jeung kurun Nabi Isa asaya fatrah (kakosongan) Nabi. Tah dina waktu harita tauhid millata Ibrahim aya nu nyelewengkeun. Pikeun ngalempengkeun deui kana rel nu sabenerna, Gusti Allah ngutus Rasulna nya eta Nabi Isa as. Anjeunna ngajak jalma-jalma Bani Israil nyemah ngan ka Allah wungkul sakumaha nu kaunggel dina ayat 51 nu geus kaliwat.

Antara kurun Nabi Isa as jeung kurun Nabi Muhammad saw lila teu aya Nabi. Harita lolobana ahli Kitab nu geus nyeleweng pikeun ngalempengkeun deui millata Ibrahim nya Gusti Allah ngutus Nabi Muhammad jadi Rasul pikeun ummat sakuliah alam. Anjeunna ngayakeun uar pangajak ka para ahli kitab sangkan baralik deui kana tauhid nu bener sakumaha nu sakumaha nu kaungel dina ayat ieu. Ayeuna, sanggeus lila dikantun ku Nabi panutup, di kalangan ummat Islam sorangan loba $n u$ nyelewengkeun tauhid, seperti, wihdatul wujud, hulul jeung tanasuh, malah aya nu mangeran ka keris, ka kuburan-kuburan, ka nu ngageugeuh hulu cai, ka nu murba wisesa di gunung jeung laut. Sajaba ti eta lain bae dina akidah malah dina ubudiah jeung muamalah ge loba nu teu aya contona ti Nabi. Tah ieu nu disebut bid'ah dhalalah.

Lamun urang bener-bener ngagem agama teh ihlas karana Allah sakuduna ngoreksi diri. Upama akidah, ubudiah jeung muamalah urang teu cocog jeung al- Qur'an jeung hadis, ku urang kudu buru-buru dilempengkeun deui. Ngalempengkeun deui agama teh enteg bangga. Entengna asal daek ngaji al-Qur'an jeung hadis, ari banggana ngalaksanakeun ngaji nu enya-enya nepi ka ngarti meujit dina pikiran karasa parat kana mamarasna. Sabab al-Qur'an jeung hadis teh ditulis $k u$ bahasa Arab. Pikeun nu teu ngarti kana bahasa Arab mah pimohaleun bisa ngarti, malah sanajan geus diterjemahkeun ge ari tetep bae hese kahartina.

b. Q.S. Al-Imran Ayat 159

Lamun urang jadi senapati ingalaga, heg aya prajurit sakompi nu ningalkeun pos lantaran haripeut $k u$ teuteureuyeun, jeung sabatalion ngaleos tanpa idin, cik kira-kirana tindakan naon nu bakal ditibankeun $k u$ urang $k a$ 
maranehna? Piraku urang teu ngambek ngagudug-gudug terus mere tindakan tegas, dikamihkeun; memeh dipecat maranehna dijebloskeun heula ka penjara.

Rasulullah mah ku lantaran geus ginuluran rahmat, dina mayunan prajurit nu indisipliner teh tetep lemah lembut, teu aya sifat sahaok kadua gaplok, tapi kalawan anteb miwejang maranehna bari ngalelemu nepi ka tembus kana sungsum, parat kana mamarasna.

Hartina: Tapi lamun hidep kasar budi tur taya rasrasan, maranehna tangtu ngajauhan hidep.

Prajurit nu ninggalkeun medan laga disebut disertir, hukuman pikeun manehna beurat kacida. Lamun Rasulullah ngayakeun tindakan keras ngumbar amarah, nyeukseukan laklak dasar bari bosongot baide amprotan, tanwande maranehna ngusap birit bari indit, ingkah balilahan ti Madinah. Batan kalulutan mah malah kalah pada naronggengan.

Hartina: Ku kituna pek hampura maranehna jeung pek ngado'a malar maranena dihampura, ajak berempug dina rupa-rupa urusan.

Rasulullah mah tara bendu kalangsu, tapi salawasna lemah-lembut tur jembar pangampura, dina basa bujangga mah anjeunna teh landung kandungan laer aisan, leuleus jeujeur liat tali. Ieu teh syarat kautamaan hiji panutan. Buruk-buruk papan jati, sanajan aya kakeuheul oge ka para disertir, maranehna teh jalma-jalma wurukaneun sabab masih suwung elmu tuna pangalaman, $k u$ anjeunna tetep dipikadeudeuh dipikaasih, dihampura tina sagala kasalahanana, dibarengan bari munajat ka Nu Maha Kawasa supaya maranehna dilubarkeun tina dosana.

Teu aya balung kulit kotok meuting, Rasulullah mah bener-bener balungbang timur jalan gede sasapuan, upama aya masalah kamasaakatan, maranehna tara tinggaleun $k u$ anjeunna diajak ngariung babadamian. Ku sabab eta sakumna para sahabat bener-bener hormat tilawat wedi asih $k a$ anjeunna ti lahir nepi ka bathin. Panutan nu mulya ahlakna, dina kadunyaan teu sarakah makmak-mekmek mangpang meumpeung kadedemes, batan rahayat katalangsara dibelaan rela marak salira, teu jejerih peurih peujit. Pamingpin nu luhung budi, geten tulaten tur someah ka somah tanwande dipikaasih dipikaajrih, para ponggawa tinangtu satia satuhu, jalma leutik ngarasa kahutangan budi. 
Lamun pangagung luhung budi, dimana aya gajah meta banteng ngamuk rahayat rela ngorbankeun jiwa jeung raga pikeun ngabela nusa jeung bangsa. Raja mukti wibawa ku rahayat didama-dama, ngarasa kerta raharja sepi paling towong rampog, murah sandang muah pangan, dina panangtayungan nu Maha Agung. Rasulullah teh picontoeun urang sarerea, kamulyaan ahlakna jadi sajatining kanasihan, lain sihir lain rajah pamunah, lain asihan leugeut teureup. Dna waktu nu kawilang teu sabaraha lilana, anjeunna geus tiasa mika ummat. Hijrah tina kafasekan jeung kafasidan kana katakwaan. Ieu te taya lian lantaran wibawa anjeunna, dipikameumeut ku nu deukeut, dipikayungyun ku nu jauh, dalit ngahiji dilahir nepi ka bathin, sawanda lir ibarat getih jeung geutah.

Lamun urang kaselir jadi patinggi, ngaheuyeuk dayeuh ngolah nagara, ulah ujub takabur jeung angkuh ku kalungguhan, loba catur tanpa bukur: hamo bisa hirup sabilulungan ku jalan nipu ngobral jangji, hamo kaimpungan $k u$ batur jeruk balarea lamun urang getah harupateun, poho kana bobot pangayon timbang taraju. Lamun ra'yat leutik geus nyungkelit atina, past bakal neuteuli hayang mulangkeun kanyeri, munajat malar urang dila'nat ku nu Maha Kuasa. Sakali deui pacuan ulah mampang meumpeung pinda pileumpangan, ulah adigung niru-niru tumenggung sundung patih arit bisi aya nu ngunek-ngunek jeung ngakalakeun upama urang geus jadi demang dongkol, da tara jaya salalawasna.

Jeung upama hidep geus gilig, sing tawekal ka Allah. Satemenna Allah teh mikasenang jalma-jalma nu tawekal.

Diluhur disebutkeu yen Rasulullah ditimbalan ngayakeun musyawarah. Timbalan ieuteh geus dilaksanakeun ku anjeunna. Basa rek ngayonan musuh dipasir uhud, anjeunna ngayakeun babadamian jeun sakumaha mujahidin babakuna jeung para pamuda. Anjeunna ngusulkeun supaya wadabala Islam henteu kaluar ti Madinah. Sedeng para hadirin miharep supaya mapag musuh diluar kota nya eta di pasi uhud. Rasulullah kawon sora, anjeunna tunduk kana putusan riungan. Ieu teh hiji bukti yen anjeunna demokrat tulen. Tapi barang anjeunna nganggo anggoan perang, aya sawatara urang nu menta ngabatalkeun putusan hasil musyawarah. Kulantaran dina babadamian tehpara hadirin geus gilig rek perang di luar, Rasulullah teu luncat Maha Kawasa supaya unggul jurit. Tapi kumaha 
kanyataan nana nu bakal kasorang, serahkeun ka nu nyepeng Qadha jeung Qaddar, tah ieu ngaranna tawekal ka nu Maha Kawasa.

Naon-naon nu ditetepkeun $k u$ mantenna $k u$ urang ditarima kalawan rela tapi lamun can nepi kana maksud, urang kudu ihtiar terus supaya ngahontal hasil nu leuwih alus. Tah ieu ngaranna Qana'ah. Tawekal jeung qana'ah teh teu meunang dipisahkeun.

\section{c. Q.S Al-Kafirun Ayat 1-6}

Aya sababaraha hadis nu diriwayatkeun ku ath-Thabrani jeung Ibnu Abi Hatim ti Ibnu Abbas, ku Abdurrazaq ti Juraij, jeung ku Ibnu Hatim ti Sa'id bin Mina, nu kasimpulanna kieu: kaom Quraisy Jahiliyah geus ngarasa teter nyanghareupan Rasulullah saw. Sakitu dihalang-halang $k u$ jalan kekerasan nu mangrupa panganiyayaan taya kendatna tapi panganut agama Islam beuki loba. Maranehna ngayakeun rapat nu ngahasilkeun hiji tipu muslihat, lamun ayena mah nu disebut kerukunan beragama atawa toleransi beragama tea. Opat jelema petingan, al-Walid bin al-Mughirah, al-Ashi bin Wa'il, al-Aswad bin al-Muthalib jeung umayyah bin Khalaf arindit nepungan Rasulullah, pok nyarita: "Yeuh Muhammad, urang teh kapan tunggal sabangsa malah seseler pisan, katurug-turug lain dengeun haseum, masih katalian kubarayaan, aya nu masih keneh karabat landep.

Ku kituna atuh sapantesna sakumaha orang Quraisy hirup runtut rukun sabilulungan $k a$ cai jadi saleuwi ka darat jadi salebak silih tulung tinulungan kapan aya paribasa buruk-buruk papan jati. Maksud kami teh kieu yeuh Muhammad, malar urang henteu pagirang-girang tampian $k u$ alatna agama, kami sakumna uran Quraisy sadia pikeun nyembah pangeran hidep babarengan jeung umat Islam lilana sataun. Sanggeus beak sataun giliran hidep jeung sakabeh umat Islam babarengan jeung kami nyembah panyembahan kami. Kitu saterusna heuleut sataun. Pingpinan ku kami diserahkeun ka hidep. "Harita Rasulullah saw teu acan tiasa maparin waleran, da anjeunna mah tara mawa karep sorangan tapi naon-naon nu dikedalkeun ku anjeunna ngeunaan urusan agama teh taya lian iwal ti wahyu. Nya teu lila ti harita turun surat ieu nu dimimitian $k u$ timbalan QullMuhammad, pok caritakeun ku hidep, yeuh kaom kafirin, kuring moal rek nyembah panembahan maraneh, jeung maraneh oge moal rek nyembah pangeran kuring. Kuring lain tukang nyembah pangeran kering. Ayeuna mah 
papadaan bae, pikeun maraneh agama maraneh, pikeun kuring agama kuring".

Surat ieu teh maraneh pisan dipake ngajawab uar pengajak jaman kiwari pikeun nagenkeun toleransi beragama. Kade ulah nepi ka ngorbankeun iman, ula-ilu kaditu-kadieu, batur ka kelenteng urang milu ka kelenteng, batur ka gereja urang milu ka gereja, lain kitu toleransi beragama mah tapi keur urang Hindu agama Hindu, keur urang Buda agama Buda, keur urang kristen agama kristen, keur urang agama urang, agama urang nya eta agama

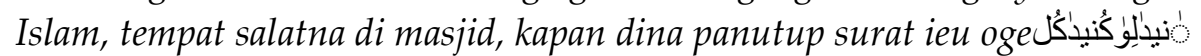

Menurut penafsiran Moh. Emon Hasim mengenai toleransi (tasamuh) yaitu ummat Islam harus saling toleransi terhadap agama lain, dalam masalah ahklak atau muamalah, tetapi dalam konteks Aqidah sebagaimana di jelaskan dalam surat al-Kafirun yaitu

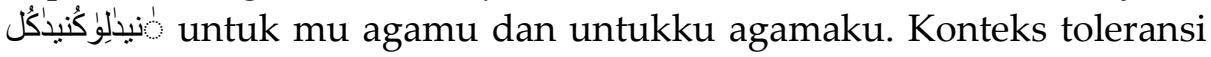
yang disampaikan oleh Moh. Emon Hasim secara substansi disampaikan melalui bahasa daerah yang lebih dapat dimaknai oleh masyarakat awam di pedesaan sekalipun dan lebih khusus pada suku sunda. ${ }^{59}$

\section{Kesimpulan}

Moh Emon Hasim merupakan mufasir yang menulis karya tafsir sunda di masa orde baru, beliau kompeten dalam bahasa dan sastra, juga merupakan permintan dari salah satu ustadz di daerahnya sehingga beliau termotivasi ingin menulis karya Tafsir ini. Makna Moderasi Islam yang dibahas dalam tafsir sunda ini yaitu, sebagai keadilan (al-Adl), keseimbangan (Tawazun), dan Toleransi (Tasamuh), Islam merupakan agama yang mudah, oleh karena itu Islam selalu bersikap moderat dalam menghadapi setiap persoalan bahkan prinsip moderasi ini menjadi karakteristik islam dalam merespon segala persoalan. Sehingga Islam yang dibawa oleh Nabi Muhammad sebagai rahmatan lil alamin. Ada beberapa Moderasi dalam lingkup Islam yaitu; Moderasi dalam dimensi Akidah, yang menjelaskan mengenai ketuhanan (Ketauhidan), Moderasi dalam dimensi Fiqh, yang

${ }^{59}$ Moh. Emon Hasim, tafsir Ayat Suci Lenyepaneun, Juz 30, 307. 
menjelaskan mengenai hukum syara (syari'at), Moderasi dalam dimensi Ahlak, yaitu memaparkan mengenai sifat/karakter sseorang terhadap agama lain, dalam toleransi, Moderasi Islam dalam dimensi politik, yaitu menjelaskan mengenai siyasah/kedudukan Negara dan seorang pemimpin. Inilah yang menjadikan Islam menjadi agama yang Moderat. Moderasi Islam dalam tafsir sunda menggunakan tafsir Ayat Suci Lenyepaneun karya Moh.Emon Hasim, Tafsir Ayat Suci Lenyepaneun yang menjadi rujukan utama dalam penulisan skripsi ini alasan menggunakan tafsir tersebut yaitu di tulis dengan kalimat yang memikat dan mudah dimengerti, tafsir tersebut di tulis lengkap 30 juz, dalam menafsirkan-Nya menggunakan peristiwa atau kejadian di Masyarakat yang relevan dengan ayat sehingga terasa masih aktual dan populer.

\section{DAFTAR PUSTAKA}

Abduh, Muhammad. Tafsir Al-Fatihah Wa Juz Amma. Kairo: Al-Hay'ah al-Ammah li Qusur as Saqafah, 2000.

Afadlal. Islam Dan Radikalisme Di Indonesia. 1st ed. Jakarta: LIPI Press, 2005.

Bakry, H. Oemar. Tafsir Rahmat Basa Sunda. 2nd ed. Bandung: CV. Angkasa, 2002.

Banua, Andi Aderus. Kontruksi Islam Moderat: Menguap Prinsip Rasionalitas, Humanitas, Dan Universitas Islam. 1st ed. Makassar: ICATT Press, 2012.

Bisri, A. Mustofa. Islam Mazhab Tengah. 1st ed. Jakarta: Grafindo Khazanah Ilmu, 2007.

Chalim, Abdul. Tafsir Soerat Al-Ma'oen. Madjalengka: Drukkerij, 1993.

Darmawan, Dadang. "Ortodoksi Tafsir: Respon Ulama Terhadap Tafsir Tamsjijatoel Moeslimin Karya K.H. Ahmad Sanusi." Fakultas Ushuluddin UIN Syarif Hidayatullah Jakarta, 2009.

Hasim, Mohammad Emon. Ayat Suci Lenyepaneun. Bandung: Pustaka Setia, 1989.

- - - Pangalaman Nyusun Naskah Tafsir Ayat Suci Lenyepaneun. Bandung: Pustaka Setia, 1984. 
-- - Rupa-Rupa Upacara Sunda Jaman Ayena. Bandung: Pustaka Setia, 1996.

Izzan, Ahmad. Metodologi Ilmu Tafsir. Bandung: Tafakur, 2011.

Juliansyah, Noor. Metodologi Penelitian. Jakarta: Kencana, 2011.

Kantor Wilayah Kementerian Agama Provinsi Jawa Barat. Tafsir AlQur'an Basa Sunda. Bandung: Pustaka Setia, 2005.

Kementerian Agama Republik Indonesia. Al-Qur'an Dan Terjemahnya. Jakarta: Lajnah Pentashihan al-Qur'an, 2005.

- - - Moderasi Islam. Jakarta: Lajnah Pentashihan Mushaf al-Qur'an, 2014.

Mide, Sabri. “Ummatan Wasathan Dalam Al-Qur'an." UIN Alaluddin Makassar, 2014.

Moleong, Lexy J. Metodologi Penelitian Kualitatif. Bandung: PT. Remaja Rosdakarya, 1989.

Rahmawati, Nor Elysa. "Penafsiran Muhammad Thalibi Tentang Ummatan Wasathan Dalam Al-Qur'an." UIN Sunan Kalijaga Yogyakarta, 2014.

Rais, M. Amien. Cakrawala Islam: Antara Cita Dan Fakta. Bandung: Mizan, 1991.

Rohmana, Jajang A. “Ideologisasi Tafsir Lokal Berbahasa Sunda: Kepentingan Islam-Modernis Dalam Tafsir Nurul-Bajan Dan Ayat Suci Lenyepaneun." Journal Of Qur'an And Hadith Studies 2, no. 1 (June 2013): 125-154.

---. Sejarah Tafsir Al-Qur'an Di Tatar Sunda. Bandung: Mujahid Press, 2017.

Romli, Muhammad, and H. N. S. Midjaja Nurul Bajan. Tafsir Qur'an Basa Sunda Juz 1. 2nd ed. Bandung: N. V. Perboe, 1966.

Rosidi, Ajib. Ensiklopedia Sunda. Bandung: Pustaka Setia, 2007.

Sanuci, Moehammad Anwar. Gajatoel Bajan (Katjida Pertelana), Tafsir Qoer'an Basa Soenda. Garut: Madjlis Ahli Soennah, 1982.

Sanusi, Ahmad. Raudhatul Al-Irfan Fi Ma'rifat Al-Qur'an. Sukabumi: Yayasan Asrama Pesantren Gunung Puyuh, 1950.

Shihab, Muhammad Quraish. Ensiklopedia Al-Qur'an Kajian Kosakata. Jakarta: Lentera Hati, 2017.

- - - Membumikan Al-Qur'an. Jakarta: Lentera Hati, 2010. 
- - - Tafsir Al-Misbah. Jakarta: Lentera Hati, 2002.

Suganda, Her, and Mohammad Emon Hasim. Bekarya Sampai Tua. Bandung: Pustaka Setia, 2002. 